\title{
Knowledge, Training and Access to Global Positioning Systems: Views of Young Fishermen in Malaysia
}

\author{
Jusang Bolong ${ }^{1}$, Nizam Osman², Siti Zobidah Omar ${ }^{1}$, Jeffrey Lawrence D’Silva ${ }^{1}$ \& Hayrol Azril Mohamed \\ Shaffril ${ }^{1}$ \\ ${ }^{1}$ Institute for Social Science Studies, Universiti Putra Malaysia, Malaysia \\ ${ }^{2}$ Faculty of Modern Language and Communication, Universiti Putra Malaysia, Malaysia \\ Correspondence: Jusang Bolong, Institute for Social Science Studies, Universiti Putra Malaysia, Malaysia. \\ E-mail: majudesa.desa5@gmail.com; jusang@fbmk.upm.edu.my
}

Received: October 16, 2013 Accepted: January 24, 2014 Online Published: February 26, 2014

doi:10.5539/ass.v10n6p19 URL: http://dx.doi.org/10.5539/ass.v10n6p19

\begin{abstract}
The main aim of this study is to identify the knowledge around, access to and training for use of a Global Positioning System (GPS) among young fishermen in Malaysia. This is a quantitative study, wherein a total of 240 young fishermen aged between 15 and 40 years old from four fishing areas have been chosen as the respondents. Based on the analyses performed, it can be seen that young fishermen in Malaysia have a good level of knowledge on the potential role GPS could play in their fishing activities. In addition, there is a lack of access to GPS training. A number of recommendations have been placed which, it is a hoped, can be used to further enhance the use of GPS among young fishermen in Malaysia.
\end{abstract}

Keywords: young fishermen, technology usage, community development, fisheries development

\section{Introduction}

The fishing industry has been long recognized as one of the catalysts that can stimulate improvement of the socio-economic level of communities in Malaysia. Today, an unpredictable climate and overfishing have posed great challenges to the fishing industry. While fishermen who practice traditional methods seem to have problems when it comes to adapting to these changes, progressive fishermen, who rely on modern fishery technologies, have successfully overcome these changes. Admitting the importance of technology within the fishing industry, the government has made efforts to introduce a number of advanced technologies, such as GPS, to the fishermen. The main function of GPS is to navigate fishermen exactly to their marked location, with this superior function having created a number of indirect benefits for the fishermen. First, it saves fishermen time-shorter fishing operations means less money spent on fuel, ice and crew member salaries and, in turn less money spent means more profit for the fishermen. Second, GPS improves the safety of the fishermen; it can navigate them directly to the jetty when visibility level becomes limited in bad weather, and can warn fishermen of any dangerous coral reef or nearby international boundaries.

Young fishermen, who are associated with their interest in and compatibility with advanced technologies, can only benefit from the use of GPS, and the same is true for future generations of fishermen-and the fishing industry as a whole. Young fishermen within the scope of this study refer to the youth fishermen. While the international definition as to what constitutes as 'youth' varies, Malaysia's Ministry of Youth and Sports, defines a 'youth' as being someone who is aged between 15 and 40 years. Currently, there is no official statistic on the number of young fishermen in Malaysia; however, local studies conducted by Shaffril et al. (2013), Mazuki et al. (2013) and Omar et al. (2012) have consistently proven that young fishermen constitute almost 30 per cent of the population of Malaysia's fishermen. It is important to have young fishermen in the industry for a number of reasons. First, the fishing population of Malaysia is aging (Ramli et al., 2013; Bolong et al., 2013). Second, as the fishing industry evolves and moves away from traditional fishing methods, it is young fishermen who can help the move more quickly toward the employment of more technologically advanced methods.

Generally, use of fishery technology among fishermen in Malaysia is still at a low level. Omar et al. (2012) have concluded that a total of 69.2 per cent of fishermen had never used GPS in their fishing operations, while only 9.7 per cent of them used it frequently. In another study by Omar et al. (2011), it was found that some fishermen 
still preferred more traditional methods than using GPS to track and navigate to marked fishing locations. Such findings give rise to an important question: even though GPS offers fishermen a number of clear benefits, the number of GPS users among fishermen in Malaysia does not reflect this-why? In response to this question, the present study would like to focus on three main factors that can explain levels of GPS usage among the fishermen of Malaysia, namely knowledge, training and access. The main aim of this study is therefore to know whether young fishermen possess knowledge on the function of GPS, and whether they are given training for and access to the use of GPS.

Knowledge is the key to success. People with knowledge in something will be more interested in it. Fishermen who are used to practicing traditional methods of fishing possess specialist knowledge of these methods, preferring to put this specialist knowledge to good use, and the same applies to those fishermen who prefer to utilize advanced technologies within their fishing operations. Therefore, training is another factor that should be focused on when it comes to encouraging the adoption of advanced fishery technologies. Consistent training should be provided to fishermen as it can educate and further encourage them to use technology (Abu Hassan et al., 2009). Training can come in two forms-formal and informal. While those in professional sectors prefer to have more formal modes of training, those in the fishing industry have been found to prefer informal modes of training (Omar et al., 2012). These findings are no surprise, as fishermen have also been found to have strong social relationships with their local community, and the process of learning therefore commonly occurs due to exchanges of information between colleagues, family members, jetty leaders and village leaders (Mazuki et al., 2013; Shaffril et al., 2013). Access to GPS is important in ensuring frequent use of GPS among fishermen. Commonly, access to funding can play a crucial role in encouraging people to use technology (Malamud \& Pop-Eleches, 2010). Those with a greater financial capacity will able to buy fishing technology and thus use regularly it within their fishing operations. Technology subsidies provide financial access to technology use, and making it available to a community-particularly to the poor within that community-is vital to supporting the adoption of technology (Shaffril et al., 2010). Furthermore, having GPS without being able to maintain it in good working order is seen as being useless, therefore access to workshops geared to repairing GPS devices would be of great help to fishermen.

\section{Methodology}

This is a quantitative study, whereby a questionnaire was developed to collect the required data. The questions included in the questionnaire were based on a literature review and the questions rose in past studies. The questionnaire consists of four parts (Table 1).

Table 1. The questionnaire

\begin{tabular}{lll}
\hline Part & Number Of Questions & Option of Answer \\
\hline Demographic & 5 & Open ended/closed ended \\
Knowledge & 7 & Closed ended (Yes or No) \\
Training & 5 & Closed ended (Yes or No) \\
Access & 5 & Closed ended (Yes or No) \\
\hline
\end{tabular}

Through a multi-stage simple-random sampling, a total 240 young fishermen from four fishing areas in Malaysia were selected as the respondents. The selected fishing areas were Langkawi Island (representing the northern zone), Pangkor Island (representing the central zone), Kuala Besut (representing the east-coast zone) and Mersing (representing the southern zone). Each area was represented by 60 respondents. The data collection was conducted in a five-month period (from February 2013 to July 2013). The data gained was then cleaned and analyzed using SPSS, where analyses such as frequency, percentage and mean score were performed.

\section{Results}

\subsection{Demographic Data}

The majority of the respondents surveyed belonged to the 36-40-years age group, while the minority of them belonged to the 26-30-years age group. The mean score for respondents' age was 31.3 . The fishing industry in Malaysia is less dominated by higher education achievers as only 4.5 per cent of them achieved tertiary-level education; this can be related to claims by Gidarakou (1997), who stated that educated young people always demonstrate less interest in agriculture, as they consider it to be a second-class job and one that is merely for generating an alternative income. Most of the respondents interviewed were experienced fishermen; 32.5 per 
cent of them had been fishermen for more than 16 years, with the mean score for experience being 12.2 years. A total of 68.7 per cent of the respondents spent more than 16 days per month at sea, which is not surprising given that in order to qualify as a registered fisherman, it is required that they spend at least 120 days per year operating their fishing routine. In line with studies done by Mazuki et al. (2013), Shaffril et al. (2013) and Omar et al. (2012), the majority of respondents were coastal fishermen (Zone A and Zone B).

\subsection{Knowledge, Training and Access to GPS}

In order to identify the respondents' knowledge about the use of GPS, they were asked a total of seven questions about GPS functions. Most of the fishermen interviewed demonstrated a good level of knowledge about the functions of GPS in fishing operations, particularly its navigation capabilities. In addition to this, they also know that GPS can also be used as a safety tool, especially in bad weather conditions and informing them on the international boundaries. A total of 24.6 per cent of the respondents were not aware that GPS could help them to avoid dangers such as coral, while a total of 24.2 per cent were not aware that GPS could help them save time and cost.

Table 2. Knowledge on GPS

\begin{tabular}{lll}
\hline Knowledge on GPS & Yes & No \\
\hline Navigate fishermen to marked fishing locations & $\mathbf{8 3 . 8}$ & $\mathbf{1 6 . 2}$ \\
Navigate fishermen to jetty in any weather condition & $\mathbf{8 3 . 8}$ & $\mathbf{1 6 . 2}$ \\
Navigate fishermen to jetty if lost at sea & $\mathbf{8 5 . 8}$ & $\mathbf{1 4 . 2}$ \\
To warn fishermen of international boundaries/limits of their & $\mathbf{8 0 . 4}$ & $\mathbf{1 9 . 6}$ \\
catchment areas & $\mathbf{7 5 . 4}$ & $\mathbf{2 4 . 6}$ \\
Avoid dangerous coral & $\mathbf{1 4 . 6}$ \\
In case of emergency (e.g. broken engine), fishermen can ask for & $\mathbf{8 5 . 4}$ & $\mathbf{2 4 . 2}$ \\
help by giving colleagues the coordinates of their location & $\mathbf{7 5 . 8}$ & \\
Save time and cost & & \\
\hline
\end{tabular}

With regards to GPS training, it is evident that informal training was common practice among the respondents, based on the fact that 42.9 per cent of them claimed that their colleagues were their best 'teacher' in training them how to use GPS, while 47.9 per cent of them practiced the technique of 'trial and error' in order to enhance their GPS skills. The higher percentage in informal training can be associated with the lower percentage of formal training available to them, with only 15.0 per cent having claimed that there were GPS courses and training offered, and only 10.0 per cent having claimed that there was an adequate number of training available to them (Table 3).

Table 3. GPS training

\begin{tabular}{lll}
\hline Training & Yes & No \\
\hline There are GPS courses and training available for fishermen & $\mathbf{1 5 . 0}$ & $\mathbf{8 5 . 0}$ \\
The number of courses and training offered is adequate & $\mathbf{1 0 . 0}$ & $\mathbf{9 0 . 0}$ \\
Training offered is free & $\mathbf{1 6 . 3}$ & $\mathbf{8 3 . 7}$ \\
My colleagues can train and teach me on GPS usage & $\mathbf{4 2 . 9}$ & $\mathbf{5 7 . 1}$ \\
I'm practicing GPS use via 'trial and error' technique & $\mathbf{4 7 . 9}$ & $\mathbf{5 2 . 1}$ \\
\hline
\end{tabular}

It is clear from the results of the analysis that the respondents are provided with poor access to GPS usage. Only 30.8 per cent of respondents claimed that they were given the opportunity to use GPS. Moreover, there is a lack of GPS rental/loan services, shops selling GPS, and repair services for malfunctioning GPS units. All of these factors can discourage the use of GPS among the respondents. In addition to this, a total of 87.5 per cent of the respondents claimed they were not qualified to request a loan to buy GPS (Table 4). 
Table 4. Access to GPS

\begin{tabular}{lll}
\hline Access & Yes & No \\
\hline There is GPS rental/loan services available at this area & $\mathbf{1 7 . 5}$ & $\mathbf{8 2 . 5}$ \\
There is a number of shops sell GPS at this area & $\mathbf{2 2 . 5}$ & $\mathbf{7 7 . 5}$ \\
There are services available for repairing dysfunction GPS & $\mathbf{2 3 . 8}$ & $\mathbf{7 6 . 2}$ \\
Eligible to apply for financial credit to buy GPS & $\mathbf{1 2 . 5}$ & $\mathbf{8 7 . 5}$ \\
Eligible to receive free GPS from concern parties & $\mathbf{2 7 . 1}$ & $\mathbf{7 7 . 9}$ \\
\hline
\end{tabular}

\section{Discussion}

Within the scope of this study, young fishermen seem to have a good level of knowledge regarding how GPS can be applied to their fishing operations. Most of them agreed on all of the GPS functions listed, particularly with regard to its navigation and safety. It is always predicted that young fishermen will possess a good level of knowledge about technology, as they tend to express their willingness to learn about how to use it (Priyanka, 2010). Priyanka (2010) then claims that young people possess high level of knowledge as resulted from the high level on interest on technology that fit their needs and ability. While it has been shown that the majority of respondents interviewed possess a good level of knowledge, the fact that a minority of them still do not know what is GPS is or how it can benefit them in their work should be taken into consideration, and it is recommended that measures should be taken to expose them to training and seminars.

The young fishermen have raised their concerns on the lack of training and courses available to them. It is recommended that consistent GPS training should be conducted by the relevant parties, as Omar et al. (2012) have stressed that continuous technology training and courses will create knowledgeable fishermen and avoid a 'seasonal attitude' towards the use of technology. Within the scope of this study, informal GPS training seems to be the most common type practiced, where almost half of the young fishermen interviewed claimed to have relied on their colleagues and 'trial and error' techniques to learn about GPS; this scenario can be explained by a number of causes. First, according to Hassan et al. (2011), interpersonal sources such as colleagues are always preferred by the agriculture community, particularly in rural areas, as they are considered to be trustworthy and reliable, and involve no bureaucracy and can easily be met. Second, Shaffril et al. (2013) have explained that fishermen have a strong attachment to their communities, and it is common practice for them to gather every evening at coffee stalls or small shelters, known locally as 'wakaf', and such gathering facilitates continuous learning, by way of information sharing between experienced and young fishermen.

Another reason as to why young fishermen prefer to rely on informal sources of information is due to a lack of access to GPS in their area. Perhaps access to financial and rental/loan services should be a focus of the relevant parties if they want to encourage and develop the use of GPS among young fishermen. Furthermore, while fishermen are actually always given access to bank credit, they are less aware about it; Ahmad Faiz et al. (2009) have explained that those in the agriculture community refuse to apply for bank loans because doing so involves a lot of bureaucracy. Free GPS or GPS subsidies should be allocated to young fishermen. Malamud and Pop-Eleches (2010) have shown that the associated agencies in countries like Brazil, Uruguay, Peru and Colombia have successfully encouraged the use of technology among the low-income group by providing technology subsidies to them. Though there are a number of programs that provide free GPS to selected fishermen, this number should be doubled, as it can increase not only the number of GPS users, but also improve skill level of GPS usage among them. In addition to this, shops selling GPS should be made available to young fishermen.

\section{Conclusion}

Knowledge, training and access are three important factors in encouraging the use of technology among a community. These three components are crucial for the future generations of the fishing industry-those young fishermen who, it is predicted, will come to rely a great deal upon fishing technologies as a response to the challenges of the fishing industry. Within the scope of this study, young fishermen are seen to demonstrate a good level of knowledge about the functions of GPS, in spite of the fact that there is a lack of access to GPS training. There is also inadequate formal training on how to use GPS, which naturally results in reliance by some upon informal training instead. The present study has concluded that finance and technology training and courses can further improve the prevalence of GPS use among young fishermen in Malaysia. 


\section{References}

Abu Hassan, M., Salleh, M. S., Shaffril, H. A. M., \& D'Silva, J. L. (2009). Problems and obstacles in using information and communication technology (ICT) among Malaysian agro-based entrepreneurs. European Journal of Scientific Research, 36(1), 93-101.

Ahmad Faiz, A. N., Khairuddin, I., Shaffril, H. A. M., \& D’Silva, J. L. (2009). Aquaculture industry potential and issues: A case from cage culture system entrepreneurs: Suggestions for intensification of aquaculture industry. Journal of Social Science, 6(2), 206-211. http://dx.doi.org/10.3844/jssp.2010.206.211

Bolong, J., Omar, S. Z., Shaffril, H. A. M., D’Silva, J. L., \& Abu Hassan, M. (2013). ICT and its implication on fishermen income in Malaysia. International Business Management, 7(2), 78-83.

Gidarakou, I. (1997). Young women's attitude towards agriculture and women's new roles in the Greek countryside: A first approach. Journal of Rural Studies, 15(2), 147-158. http://dx.doi.org/10.1016/S0743-0167(98)00054-0

Hassan, M. S., Yassin, S. M., Shaffril, H. A. M., Othman, M. S., Abu Samah, B., Abu Samah, A., \& Ramli, S. A. (2011). Receiving the agriculture information through mass media and interpersonal sources among the rural community. American Journal of Agriculture and Biological Science, 6(3), 451-461. http://dx.doi.org/10.3844/ajabssp.2011.451.461

Malamud, O., \& Pop-eleches, C. (2010). Home computer use and the development of human capital. The Quarterly Economics, 126(2), 987-1027. http://dx.doi.org/10.1093/qje/qjr008

Mazuki, R., Omar, S. Z., Bolong, J., D’Silva, J. L., \& Shaffril, H. A. M. (2013). Social influence in using ICT among fishermen in Malaysia. Asian Social Science, 9(2), 135-138.

Omar, S. Z., Abu Hassan, M., Shaffril, H. A. M., Bolong, J., \& D’Silva, J. L. (2011). Information and communication technology for fisheries industry development in Malaysia. African Journal of Agriculture Research, 6(17), 4166-4176.

Omar, S. Z., Shaffril, H. A. M., D'Silva, J. L., Bolong, J., \& Abu Hassan, M. (2012). Usage of offshore ICT among fishermen in Malaysia. Journal of Food, Agriculture and Environment, (3\&4), 1315-1319.

Priyanka, M. (2010). Mobile phone usage among youth in India. Retrieved June 28, 2013, from http://drum.lib.umd.edu/handle/1903/10255

Ramli, S. A., Omar, S. Z., Bolong, J., D’Silva, J. L., \& Shaffril, H. A. M. (2013). Influence of behavioral factors on mobile phone usage among fishermen: The case of Pangkor Island fishermen. Asian Social Science, 9(5), 162-170. http://dx.doi.org/10.5539/ass.v9n5p162

Shaffril, H. A. M., Abu Samah, B., Abu Hassan, M., \& D'Silva, J. L. (2010). Socio-economic factors that impinge computer usage in administration works among village leaders in Malaysia. Scientific Research and Essays, 5(23), 3623-3633.

Shaffril, H. A. M., Abu Samah, B., D'Silva, J. L., \& Yassin, S. M. (2013). Social adaptation towards climate change among Malaysian fishermen. International Journal of Climate Change Management and Strategies, $5(1), 38-53$.

\section{Copyrights}

Copyright for this article is retained by the author(s), with first publication rights granted to the journal.

This is an open-access article distributed under the terms and conditions of the Creative Commons Attribution license (http://creativecommons.org/licenses/by/3.0/). 